\title{
Citizenship without Belonging? Contesting Economic Space in Oman
}

\author{
Crystal A. Ennis \\ Institute for Area Studies, Leiden University, Leiden, The Netherlands \\ Corresponding author. E-mail: c.a.ennis@hum.leidenuniv.nl
}

How do perceptions of not belonging inform economic life? For many young Omanis, the labor market is a site of contestation and a space of struggle. In this essay, I explore a neglected dimension of belonging in the Gulf-citizen labor-by looking at Omani millennials in the labor market. ${ }^{1}$ Despite holding legal citizenship, a sense of belonging remains elusive in much of the private sector. Many Omani young people perceive a tenuous economic citizenship, complicating narratives around belonging or not belonging in the Arabian Peninsula. I draw from lessons learned while researching my current book and exploring social relations and regulation of labor markets, and reflect on how the knowledge and theories produced concerning Gulf labor markets rarely engage with the citizens in them.

Political economy scholarship on the region has for too long been missing the voices of people, instead relying on arm's-length theorizing. To understand economic belonging among Omani citizens, we need to listen to their voices and experiences of work and economic life. Because Omani citizens hold only 12.5 percent of jobs in the private sector, a structural feature common across Gulf countries, they are usually relegated to a statistical note of economic organization. This feature is explained as the by-product of a rentier economy or written off with tropes about a so-called rentier mentality or Gulf work ethic. Assumptions that economic spaces are not political and that economic analysis is objective seem to condone the persistence of Orientalist takes that have not only normalized an "othering" gaze but also have formed the basis of scholarly interpretations of the region's economy. Such analysis has ignored the colonial histories that shaped labor markets in the Gulf. ${ }^{2}$ Moreover, it has missed how economic belonging manifests among various labor market participants. ${ }^{3}$ It is time to bring citizens back into the analyses.

Economic life in Gulf labor markets is shaped by contested belonging. Belonging takes different forms, determined by who has access to jobs, income, and legal status, as well as who feels they should have access to jobs, income, and legal status. ${ }^{4}$ Not belonging manifests in different ways, but it is a feeling shared and experienced in everyday life. Economic and political exclusions go beyond the question of who has a passport. Many of our studies of labor and belonging in the Arabian Peninsula evoke images of

\footnotetext{
${ }^{1}$ The term millennials here refers to young adults born roughly between 1980 and 2000, who are early career university graduates and school leavers.

${ }^{2}$ For a detailed discussion of the colonial origins of the labor sponsorship system in the Gulf and policies for controlling labor, see Omar AlShehabi, "Policing Labour in Empire: The Modern Origins of the Kafala Sponsorship System in the Gulf Arab States," British Journal of Middle Eastern Studies (2019), doi: 10.1080/13530194.2019.1580183.

${ }^{3}$ Ahmed Kanna is among the rare scholars chipping away at forms of citizenship subjectivity in Dubai; "Flexible Citizenship in Dubai: Neoliberal Subjectivity in the Emerging "City-Corporation,"” Cultural Anthropology 25, no. 1 (2010): 100-29. Likewise, through her case study of Indians in Dubai, Neha Vora's work is pioneering in advancing our thinking on forms of belonging in the Gulf. In her case we see the reverse: belonging without citizenship; Impossible Citizens: Dubai's Indian Diaspora (Durham, NC: Duke University Press, 2013).

${ }^{4}$ It is important to note that many Omani expatriate social and workplace relations are smooth, positive, and productive. Oman is often experienced as a regional outlier in this regard, with a great deal of social overlap and friendships, especially among educated middle and upper classes. This reflection, however, is centered on understanding relations and experiences of the "left out"- those who sit on the margins of inclusion.

(c) The Author(s), 2020. Published by Cambridge University Press. This is an Open Access article, distributed under the terms of the Creative Commons Attribution-NonCommercial-NoDerivatives licence (http://creativecommons.org/licenses/by-nc-nd/4.0/), which permits non-commercial re-use, distribution, and reproduction in any medium, provided the original work is unaltered and is properly cited. The written permission of Cambridge University Press must be obtained for commercial re-use or in order to create a derivative work.
} 
expatriate workers and the circumstances that determine the conditions, duration, and rights in which they work and live in the region. The Gulf citizen is absent, assumed to be a uniform privileged actor by virtue of the power and access derived from a passport. But these experiences of belonging and not belonging co-constitute the other and are present between and below everyday social and class relations.

Speaking about economic life in terms of belonging allows us to access the missing nuance of labor market realities in the Omani economy. It provides the opportunity to address employment precarities and policy responses to them, and how these responses cause oscillating senses of vulnerability and belonging-where moves to enhance the job security of citizens magnify the sense of insecurity and precarity of the country's many noncitizens. In the remainder of this essay, I discuss encounters that tell us something about being on the margins of belonging, about layers of exclusion, and about pressures to be a good, productive economic citizen.

Oman's labor market is one in which nearly 80 percent of employed persons are expatriates, available work is primarily found in the private sector, working foreign men vastly outnumber working women, and the greatest number of jobs are in low and semiskilled occupations in the construction industry and service sector. ${ }^{5}$ These sectoral and citizenship segmentations are further gendered, raced, and classed. ${ }^{6}$ Yet one of the country's great social policy issues is unemployment. With nearly 74 percent of the Omani population under the age of 35 and growing numbers of college and university graduates entering the workforce each year, the issue of jobs is pressing. ${ }^{7}$ The matter first drew wide public attention during the demonstrations of the 2011 "Omani Spring," yet these pressures were building long before. Demands from job seekers have continued in the decade since, while new jobs added to the economy continue to be filled through foreign recruitment. As Ann al-Kindi notes, this unemployment problem is "a strange type." ${ }^{8}$ Encountering unemployment when there is no shortage of jobs is indeed bewildering for many young Omani job seekers.

Such encounters also help explain the trending Twitter hashtags such as 'Omāniyūn bilā wazāìf (Omanis without jobs) and bāhathūn 'an 'aml yastaghaythūn (job seekers are calling out), which have continued since the oil price downturn in late 2014. A quick look at the National Employment Centre job vacancy page is telling. At the time of writing, one advertised position for a system engineer and one for a secretary respectively drew 892 and 896 applications within only one week of posting. With the deepening of the oil price crisis since the coronavirus pandemic upturned the global economy, calls for jobs from Omani young people grow louder as jobs grow scarcer: "nurses without jobs," "Omani doctors working without employment," "direct recruitment for teachers," and "the excluded seek help from the sultan." Such hashtag cries on social media in 2020 join the chorus of national employment demands that have maintained a steady pace since late 2017 when small physical protests once again occurred.

Many tweets simply beckon for jobs, some share failed recruitment experiences, and occasionally some show screenshots of job ads posted to recruit expatriate professionals for the same fields in which they cannot find work. Reem, described on her new Twitter profile as a job seeker and 2015 sociology graduate of Sultan Qaboos University, expresses some exasperation:

We returned many times to the ministries (Ministry of Education, Ministry of Civil Services, Ministry of Finance, Ministry of Manpower, Ministry of Social Development), to make inquiries into our fate and our future that troubles us. But to no avail!! We have become like a ball which everyone throws to the other!!!"10

Another account (using the handle "Oman first") asks more poetically,

\footnotetext{
${ }^{5}$ Calculated from NCSI, 2019 Statistical Year Book (Muscat: National Centre for Statistics and Information, 2019), https://www. ncsi.gov.om/Elibrary/Pages/Home.aspx

"I use "raced" instead of "racialized" intentionally, following the idea that markets "take their modern forms as raced," not as outcomes of rational capitalism subsequently distorted and racialized; David Roediger, "Raced Markets: Prefatory Note," New Political Economy 23, no. 5 (2018): 531-33, https://doi.org/10.1080/13563467.2017.1417365.

${ }^{7}$ NCSI, 2019 Statistical Year Book, 83.

${ }^{8}$ Ann al-Kindi, "Muqawama al-'Aqaliyya al-Ri'iyya'," 5 November 2017, https://annalkindi.net/archives/2030.

${ }^{9}$ Author translations.

${ }^{10}$ Reem, Twitter post, 14 June 2020, https://twitter.com/reeem11333/status/1272198736358395904; author translation.
} 
bimā at-t'allul là shughul wa là 'amal

wa lā ma'àsh wa lā māl wa là amal!!?

(By what reasoning, no job, and no work, and no salary, and no money, and no hope!!?) ${ }^{11}$

Tagged in this tweet are the Ministry of Manpower and the Centre for National Employment. At times, local poets also engage with poetry. These speak of the rosy, yet "simple" dream of a job, and often beseech the sultan to answer these calls. ${ }^{12}$ It is hoped that the one who holds the most power can deliver on their dreams and expectations.

This unemployment might be intentional as much as it is strange. At least it is the outcome of years of the neoliberalizing tendencies of the global political economy, with capital and labor mobilities trailing the pull of global value chains. Next to oil income, a flexible, low-income workforce is the foundation of the regional development model. Oman's location within a regional political economy positioned within a global labor market allows it to draw workers from global supplies. Capital's thirst for cheap labor is never quelled and has nurtured Gulf labor markets to grow accustomed to looking beyond borders in search of the most inexpensive and flexible labor across skill levels. "Flexible" is a euphemism for labor that is legally expendable and expeditiously dismissed.

If the Omani labor market can be characterized in one way, it might be that economic activities and social relations are undergirded by an impression of not belonging. In 2010, 'Ali al-Kuwari described society and social relations in the Gulf as transitioning to a labor camp. In his view, certain modes of development in the Gulf facilitate this social structure, characterized by a multicultural, multi-faith, and multiethnic society that communicates in English and has a minority of indigenous citizens. ${ }^{13}$ This is a potent reflection that underlines the impact of the workplace on everyday social life. It becomes even more vivid when read alongside tensions about economic belonging and the right to jobs.

Snapshots of labor market experiences offer glimpses into the margins of belonging. The young Omani university graduate, already two years on the job market and finding no opportunity. The aging expatriate, retiring after a forty-year career in the country, having to leave and wondering where home is. The young Omani in a newly nationalized job but feeling excluded from learning and knowledge transfer. The expatriate who worries that by training a fresh Omani graduate on the job he will make himself redundant. The Omani feeling excluded from a team discussion or decision-making process as colleagues and the boss carry out work conversations in their native tongue. Each of these snapshots reflect real stories I was told repeatedly from across the country. Many who call the Gulf home will find them familiar. It is a strange place to hold what is a coveted passport and yet feel situated on the margins of belonging - one person's precarity hinging on the precariousness of the other.

Where one sits along these margins of belonging is fluid and moves with policy measures. In itself, labor market governance is a contested space where the government is mired between opposing pressures: first, to liberate the private sector and deregulate the labor market to ensure easy access to cheap, flexible foreign labor, and second to protect Omani national labor interests. The cornerstone for local labor protection is nationalization policies known locally as Omanization ( $\left.\mathrm{ta}^{\mathrm{i}} \mathrm{min}\right)$. These include human capital development (like education and training) on the one hand, and more direct labor market interventions like reserving a certain percentage of positions for citizens on the other. The state also selectively increases the barriers to foreign recruitment by measures like temporary visa caps, banning visas for certain professions, or increasing visa costs. The private business community, multinationals, and local capital lobby to ease all associated Omanization measures, calling them cumbersome and revenue-hurting. At the same time, the ranks of unemployed graduates push for more economic opportunities. All sectors face these stresses, and pressure grows during periods of low oil prices. Policy measures aimed at finding positions for Omani graduates have inverse ramifications for a migrant workforce who, when hearing the louder public discourse of Omanization, fear the loss of their jobs.

\footnotetext{
${ }^{11}$ The English translation loses the poetry of the words (Wațan min shams); Oman First, Twitter post, 23 June 2020, https:// twitter.com/Omanfirst966/status/1275357461638254593.

${ }^{12}$ See for example, Qasim al-Gharaibi, Twitter post, 18 June 2020, https://twitter.com/qmg317/status/1273658515417161729; and Ahmed al-Maamari, Twitter post, 7 June 2020, https://twitter.com/ahmed_alm3mari/status/1269666370901458950.

${ }^{13 ،}$ Ali al-Kuwari, "Makhatar al-Siyasa al-Amrīkiyya wa Tahdiyat Muwwajatuha: Hala Duwwal Majlis at-Tacaauwwun," 16 March 2010, http://dr-alkuwari.net/node/125.html.
} 
A clear example of this pattern occurred when job seekers began mobilizing again in late 2017. The government responded swiftly, in a way that seemed to mirror the announcement of 50,000 new jobs to quell protests in the "Omani Spring." This time, the government said it would create 25,000 jobs within six months. A crucial difference quickly became obvious: these jobs could not all be found in the public sector. The government made public pleas for private sector establishments to "take the initiative and shoulder their national responsibilities" to employ Omanis. ${ }^{14}$ Some larger companies also received long lists of job seekers from the national registry to select candidates from, sometimes with expected hiring numbers. The government also announced it would temporarily stop issuing expatriate visas for eighty-seven occupations for the first half of 2018. By May of the same year, 161 companies were fined for not hiring even one Omani citizen. The visa ban was extended and amended throughout 2019. ${ }^{15}$ If fewer expatriates can attain visas for jobs, perhaps more Omanis can hold them. This is the underlying logic, but it serves to offload precarity onto the "flexible" labor market participants. Historically such moves barely stymie the inflow of labor, and when the economic climate improves restrictions quickly relax. Yet even the announcement of such measures ties the economic fortunes of one community on the margin to another. It is in this tension, this competition around perceived economic rights, that anti-immigration sentiment and national chauvinism can fester. ${ }^{16}$

In conversations, surveys, and interviews, young Omanis offer diverse explanations for the cause of youth unemployment in the country. Common themes include government mismanagement, corruption, nepotism, and expatriates filling jobs. The latter comes up repeatedly, often with an impression that employers explicitly favor expatriates over Omanis. The private sector is perceived as an economic space for South Asians, where, for example, Malayalis (Keralites) only want to hire Malayalis, and Bengalis Bengalis, and where business deals are facilitated by which Malayali purchaser knows which seller. Omanis are only a necessary intermediary when mandated by the state, like the requirement for bureaucratic paperwork to be filed by an Omani public relations officer. Young people give similar reasons for why more of them do not work in the private sector, which are conveyed alongside concerns about working conditions like long hours, low salary, and limited job security. Several young people expressed the feeling that they were excluded from private sector jobs because managers and supervisors were foreign. "Because Indian people don't want us," explained one. Such impressions allude to growing tensions and the potential for rising populism in a place where cross-national interaction is generally stronger and more positively viewed than in neighboring states. These are the risks in labor markets so deeply divided.

One can disentangle the story of belonging further and find class, race, access, and gender divisions within and across the Omani citizenry. Despite rather successful Omani national identity building, Sa id al-Hashimi notes that the Omani middle class is still shaped by competing identities of local regionalism, tribalism, and

\footnotetext{
${ }^{14}$ Ministry of Foreign Affairs, "25,000 Jobs for Omanis in Public, Private Sectors,” 5 October 2017, https://www.mofa.gov.om? $\mathrm{p}=10333$ \&lang=en.

${ }^{15}$ Times News Service, "161 Companies Penalised for Violating Omanisation Law," Times of Oman, 14 May 2018; "Visa Ban on 87 Jobs in Private Sector Extended: MoM,” Muscat Daily, 4 February 2019, https:/www.pressreader.com/oman/muscat-daily/ 20190204/281479277654342.

${ }^{16}$ The job space for citizens and noncitizens continues to tighten as the economy slides toward scarcity. By the end of the 2019, the media reported that over 2,200 Omanis were laid off from a collection of large industrial and construction companies, adding to the ranks of the unemployed. A moratorium on foreign worker visas in construction and cleaning activities was announced, and in early 2020 the Ministry of Manpower said that existing visas of expat sales representatives and purchasers would not be renewed to make way for Omanis. By April, state-owned enterprises were told to replace expatriates with Omanis. By May, expatriates learned that in the new year they would be able to switch jobs in the country more easily when the requirement to have a non-objection certificate or face a two-year visa ban would be removed. This will facilitate the mobility of foreign labor within the country, and was welcomed by expatriates. As 2020 moves on and the twin crises of the coronavirus pandemic and oil price slide deepen, more such measures are being announced. Times News Service, "More than 2,200 Omanis Laid off in 2019," Times of Oman, 2 December 2019, https://www.zawya.com/mena/en/economy/story/More_than_2200_Omanis_laid_off_in_2019SNG_161042009; Zainab Mansoor, "Oman to Not Renew Work Visas for Expats in Certain Professions," Gulf Business, 6 February 2020, https://gulfbusiness.com/oman-to-not-renew-work-visas-for-expats-in-certain-professions; "Finance Ministry Issues Circular No. 14 on Omanisation Policy in Government Firms” Oman News Agency, 29 April 2020, http://omannews. gov.om/description_bkp/ArtMID/867/ArticleID/12330/Finance-Ministry-Issues-Circular-No-14-On-Omanisation-Policy-inGovernment-Firms; Times News Service, “Oman Removes NOC, Expats Can Switch Jobs,” Times of Oman, 7 June 2020.
} 
community ties. ${ }^{17}$ In the context of everyday economic life, certain communities are sometimes perceived to dominate particular industries, and certain forms of work are believed to be better suited to particular communities or genders. The feeling of being on the margins exacerbates such perceptions of difference.

Another experience of not belonging comes from informal barriers to career mobility and learning within a job. Over the years, I regularly heard employers speak of the "tax" of Omanization-a job you must offer even without a vacancy. It was considered a cost of doing business. Young people receiving this "phantom employment," as Steffen Hertog calls it, quickly find themselves frustrated, bored at a desk without anything meaningful to do. ${ }^{18}$ Meanwhile, some who do secure an actual job express frustration at being excluded from learning opportunities. Nurses tell me about their requests that patient care be discussed in English or Arabic, because foreign doctors and nurses often consult with each other in their shared native tongue while Omanis stand idly by. Newly recruited technicians and engineers tell me about trying to learn a new technical process but being sidestepped or ignored as a team of expatriates complete the job. Stories are plentiful. Omani economists also critique these patterns for preventing accumulated knowledge, skills, and innovation from being shared across the economy and for keeping the Omani structurally dependent on the expatriate even at an individual level. ${ }^{19}$ Some of these exclusionary behaviors may be unintentional, whereas others may be interpreted as strategies: strategies to remain, strategies of preservation when your livelihood is marked by precarity.

Although many young people still expect the state to be both welfare and job provider, there is wider realization that the opportunities now are different than they were for their parents' generation. With shrinking prospects in the public sector, more young people choose to delay graduation so as to collect a small educational subsidy and delay the job-wait period, or even go on to pursue further educational opportunities. Such forms of underemployment and disenfranchisement escape accounting. That is, the delay of work, of marriage and family building, and the inability to earn a living and contribute to the family also build a feeling of being excluded from participation in expected social norms and processes. This, too, is another form of not belonging.

Related to this, a sense of belonging rooted in collective nation building also is challenged. The idea that it is necessary to get a good, secure job to care for your family and to contribute to building your country is impressed upon young people by family and educators and throughout society. Not only this, but decades of developmental discourse by economic planners and political leadership has repeatedly called on young people to contribute to building the Omani nation through work. Such narratives treat work as a patriotic duty and national responsibility. ${ }^{20}$ Yet when today's young people enter the job search, they enter a space where government jobs are scarce and the private sector is unwelcoming.

One of the ways the government addresses this gap is through the promotion of entrepreneurship. Entrepreneurship is offered as a way to save the nation from the job-seeking epidemic. Viewed in international development policy as a solution to unemployment, educators and policy-makers impress upon youth the importance not just of a good job to build the nation, but also of creating a good business. It is a neoliberal paradigm equating entrepreneurship with citizenship; an imagined way to facilitate economic belonging in the private sector. If you cannot find a job in your field, surely you can make your own! Entrepreneurship as a form of self-employment, and thereby a means of privatizing and individualizing the employment burden. ${ }^{21}$

\footnotetext{
${ }^{17}$ Sa 'id Sultan al-Hashimi, “'Uman: 'an Masala al-Tabaqa, wa fi Musa'la al-Wusta,” al-Mustaqbal al-'Arabi, no. 495 (2020): 71-72. For a detailed study of Omani national identity building since 1970, see Marc Valeri, Oman: Politics and Society in the Qaboos State (London: Hurst, 2009).

${ }^{18}$ Steffen Hertog, "Arab Gulf States: An Assessment of Nationalisation Policies," GLMM RP No. 1/2014 (Gulf Labour Markets and Migration, 2014), https://cadmus.eui.eu/bitstream/handle/1814/32156/GLMM\%20ResearchPaper_01-2014.pdf?sequence= 1 \&isAllowed $=\mathrm{y}$.

${ }^{19}$ Sa id al-Saqri, "al-Khazina al-'Addad 18 November 2013," Cosmologymass (blog), 13 December 2013, http://cosmologymass. blogspot.com/2013/12/13.html (accessed 1 June 2020); "Muraqibun wa Muhalalun Iqtisadi li-l-Watan al-Iqtisadi: Duwwal al-Majlis fi Khatar wa La Bad min Siyasat Siría li-Tanawiyy'a Masadar al-Dakhil,” al-Watan, 4 November 2014, http://alwa$\tan$. com/details/37154.

${ }^{20}$ Development plans, royal speeches, and statements from ministers of finance, among others, over the decades are rife with the language of work as a shared responsibility toward national development.

${ }^{21}$ Crystal A. Ennis, "The Gendered Complexities of Promoting Female Entrepreneurship in the Gulf," New Political Economy 24, no. 3 (2019): 365-84, https://doi.org/10.1080/13563467.2018.1457019.
} 
The added hope has been that entrepreneurship would contribute to job creation. Yet in keeping with existing economic structures, this form of employment generation also adds to foreign rather than Omani recruitment. New small- and medium-sized enterprises (SMEs) successfully lobby the government for exemptions from nationalization quotas, with the rationale that hiring locals, who require higher wages, better benefits, and shorter working hours, is damaging and kills competitiveness. ${ }^{22}$ Starting one's own business is no easy task for a new, young job seeker when one considers that new businesses have high failure rates around the world. Without success, the individual now bears the blame for not working hard enough, not being successful enough. And when personal income is secured through those elusive successes, profitability again depends on a "flexible" workforce.

The forms of exclusions that greet job seekers in the labor market are multilayered and imbued with contention around who belongs and how one belongs. Most obvious are young Omanis who feel they are denied economic opportunities, as they observe expatriates recruited from abroad fill positions they feel themselves qualified for and have a right to. Other exclusions manifest on the job, in career mobility, and in the promise of entrepreneurial salvation. The workplace is a site of contestation. Crisis moments have a tendency to heighten growing malaise. As described in this piece, Omani young people, despite holding political citizenship and despite appearing to be those who belong most and benefit most, face multiple exclusions in their economic citizenship and feel marginalized in private sector engagement. Certainly, Omanis benefit from particular privileges, like wages and land plots, in comparison to other members of society. The depth of privilege varies by class, gender, and access. However, senses of not belonging or feeling restricted from economic engagement inform economic choices, influence economic life, and have very real implications for social and labor relations and for state-society relations.

Such exclusions are grounded in the economic structures of segmentation and bound up in the dialectic of neoliberal reform in conflict with labor protection. These social relations, underpinned by persistent impressions of not belonging, have been overlooked. The structure of the labor market has been normalized as an exceptional feature in political economy analysis of the country and region. Although the scale of foreign labor dependence is indeed distinctive, segmentation is not. The global labor market is both classed and raced; and "complex forms of subordination of labor to capital arise-wage labor, family labor, indentured service and enslavement-and the different forms are socially constructed (and resisted) and politically regulated." ${ }^{23}$ What has been missing from much of the Gulf political economy discourse is how these engagements and social entanglements are socially constructed, resisted, and regulated. We can only begin to comprehend this by listening and engaging with the voices of those who experience everyday life in the Gulf labor market.

Acknowledgments. A multitude of thanks are due to Gwenn Okruhlik for convening this roundtable, offering helpful feedback on earlier drafts, and for keeping us organized and encouraged during this challenging year. I would also like to thank the other contributors to this roundtable and Kawthar Al-Harthy for their insightful comments.

\footnotetext{
${ }^{22}$ In 2015, the government granted new SMEs a two-year exemption from Omanisation regulation, allowing full dependence on an expatriate staff; "Government to Ease Omanisation Norms for SME Sector: H. E. Sunaidy," Muscat Daily - MENAFN, 28 January 2015, https://www.menafn.com/qn_news_story_s.aspx?storyid=1094090248\&title=Government-to-ease-Omanisationnorms-for-SME-sector-H-E-Sunaidy\&src=RSS.

${ }^{23}$ Gurminder K. Bhambra and John Holmwood, "Colonialism, Postcolonialism and the Liberal Welfare State," New Political Economy 23, no. 5 (2018): 579, https://doi.org/10.1080/13563467.2017.1417369.
}

Cite this article: Ennis CA (2020). Citizenship without Belonging? Contesting Economic Space in Oman. International Journal of Middle East Studies 52, 759-764. https://doi.org/10.1017/S0020743820001063 